\title{
Horrorspace: Reading House of Leaves
}

Fred Botting, Kingston University

\section{Abstract}

Absence is crucial to the evocation of horror, marking out limits to sense, knowledge and representation. Linked to space, horror's architectural, anthropological, philosophical and literary dimensions open up to darkness, emptiness, revulsion or dread, to raise questions of rationality, the sacred, home, corporeality and human subjectivity. Horror's movements broach an otherness that is both unpresentable and intimate, imaginary and real. House of Leaves, a text situated in a fissure between modern, postmodern and post-human articulations of walls, words and webs, both registers and resists changes in contemporary modes of literary production, recording and reading. Yet, engaging digital and media forms in a dense aesthetic network of allusions, the novel's use of familiar and disturbing spaces and figures such as house, labyrinth and void reworks horror's textual and affective armoury. It also foregrounds generic techniques and effects like terror, doubling and excess, patterns that have been in play since the eighteenth century as modes that have preceded and enabled the emergence of post-Romantic literary values.

This is the peer reviewed version of the following article: Botting, Fred (2015) HORRORSPACE: Reading House of Leaves. Horror Studies, 6(2), pp. 239-254. ISSN (print) 2040-3275, which has been published in final form at http://dx.doi.org/10.1386/host.6.2.239_1. 


\section{Keywords}

space

architecture

the sacred

horror

otherness

(post-)humanity

materiality

absence

Horror has caused this. But where horror? Why horror? Horror of what?

(Danielewski 2001: 494)

Horror as 'cause', as locus of alterity, law and decomposition, has been well documented as 'Thing'. ${ }^{1}$ But its 'whys', wailing like sirens of an indeterminate emergency, only pose questions of location, reason, objectivity: if place, rationality and the world of things are sites from which horror extracts diversely reiterated demands for identification, explanation or reason, any refusal of answer indicates little more than the incapacity of rational or empirical discourses to apprehend it. Failing to account for horror only emphasizes that it is 
not their thing, not within grasp yet still intrusive, prompting their questions and, in turn, asking more. Why? Without the answer of a superior entity, a simple yet terrifying just because' is evoked, just another question of a reason for being, posed darkly or otherwise: 'there is... horror'. 'What?' receives only a plethora of negations of reason and (common) sense (occult forces, superstition, madness, demons, death, nothing, or, pure and simply, evil). Negatives mark only a lack and a limit: absence of reason or knowledge; loss of sense or sanity. Horror, however, possesses strange and tangible resources, sonic, odorous, oneiric, affective, intimations of (un)real presence repeatedly registered as chills, nausea, dread, anxiety, shudder, gasp and scream. Its names may be negative, but they are also legion. Its negatives, moreover, refuse resolution. They are double: neither real nor unreal, matter nor spirit, natural nor unnatural, object nor subject; horror, animating and refusing opposition, signals something Thing other. ${ }^{3}$ Insubordinate, it does not stay in place.

'Where?', then, becomes a pressing and elusive question. Beyond, below, behind (it is rarely above and only temporally before), horror lies between, traverses limits, thresholds, borders and solid walls, a no-place testing, on all sides, within and without all things, law, border, security and comfort. ${ }^{4}$ Above all, home. It lives, but never alone; an in-habitation, it feeds, it hosts, it spooks and scares, cries, crawls, creeps and crashes. Close by, it keeps its distance, intimate and otherwise. Crossing boundaries, it demarcates spaces and brings things and selves into being just as surely as it destroys sanctities and securities. Primal yet residually modern, horror's incursions - shocking, eerie, sacred, violent and revolting - are both time-less and place-less and intimately tied to specifically human-more-or-less-thanhuman moments and sites, sometimes formless, sometimes sacred and sometimes other. ${ }^{5}$ 


\section{Horrorspace}

Horrorspace: horror space. More directly, space itself. ${ }^{6}$ Ambivalently - even in-differentlyhuman and modern, horrorspace is doubled. Rife with anxiety, dread, its disorientations promise total dissolution: a limit to sense, knowledge and understanding, it delivers a pulse of recoil where boundaries are recovered - sense, body, self, re-established on the verge of collapse. Hence the revolting intimacy between subjects of civilized and rational modernity and horror, a limit that remains uncertain, mobile, permeable and yet absolute, at once a matter of ambivalence (interior and exterior, in-secure, assurance and threat, protection and danger, caution and invitation). Horror does not simply mark out an uncrossable line an absolute law - but occasions an anxious encounter in which lines waver, dissolve and perhaps reform. Proximity of loss allows limits to be restored even as a promise is glimpsed - horror's invitation to move beyond - of something awful, sacred, other. Or something else. A different fissure; a disturbing flicker: between modern materialities of text and writing (based on presence and absence) and a cybernetic order of pattern and randomness shaping rapid circulations of bits of information lies 'fissured space' (Hayles 1999: 28).

In House of Leaves horrorspace is pushed to extremes, from a sacred nowhere and full nothingness to an indifferent no-space. Its wide play of allusions, direct citations, fragments and fabrication of past writings from multiple sources (classical, popular, fictional, philosophical, cinematic, televisual, critical, scholarly), an extravagant literariness enhanced by highly formalized deployment of diverse formal and typographical styles (from extended footnotes, to columns, boxes, diagonal lines and barely a word per page). Yet this manifestly and excessively textualized form also relates to non-analogical, non-print-based modes of mediation, like hypertext and digital coding: a 'technotext' or 'a figure for the labyrinth of 
the digital' (Hayles 2002: 802; Hansen 2004: 628). Early impressions printed the word 'house' as 'house' - in slight superscript (suggestive of typewriting or typesetting malfunction) and in blue ink: blue is the colour of a hyperlink and of the screen background used in film for post-production projection or animation (Hayles 2002: 792). Extracts were posted online in PDF format before publication. Hypertext, network and multimedia dominate critical discussions. Postmodern play prefigures fictional immersion in digital technologies heralding the end of an era of print, meaning, reference and reality. ${ }^{7}$ The move, leaving modernity behind, also raises questions of the status of human subjects, of the literature celebrating self and of the horror that marked the very limits of human existence.

House of Leaves keeps returning to horror, extends its formal and affective range at the same time and in the very same gesture: repetitive escalation of techniques and topics and incessant self-reflexive commentary threaten exhaustion. It begins with the generic limits it needs and exceeds: the film footage at its heart - a documentary record of dubious provenance detailing disturbing occurrences in a family house - is marked by and escapes generic classification. The Navidson Record is 'uneasily contained', the narrator-editor comments: even 'if finally catalogued as a gothic tale, contemporary urban folkmyth, or merely a ghost story' it 'will still, sooner or later, slip the limits of any one of those genres'. Too much tends to 'jut out past the borders' (2001: 3). Borders and limits, whether psychical, architectural or geographical, are precisely where horror plays itself out. But to gauge the uncontained horror of the text, familiar contours must be exploited and exhausted. The account's second 'editor' - and surrogate reader -is consumed by the writing and horror that envelops him: a nameless dread insistently dogs his efforts to shape the fragments left by the mysterious old man - Zampanò - who had researched and 
prodigiously commented on the case. Multiple, reflexive reference, an excess of evidence, criticism and commentary, madden and disorient him: he continues, pressed by 'some misunderstood desire to finish The Navidson Record' (2001: 297). To close the torturous and complex text would turn its spatial involutions into an object delimited in space and time and allow the young part-time Los Angeles tattooist, Johnny Truant, to disarm dangerously animate effects into safe dead letters: to 'reinter this thing in a binding tomb', contain horrifying vitality, 'make it only a book' (2001: 327). Thus to catalogue and shelve it, fix it with genre. Long literary labours effect the opposite: writing envelops, displaces, horrifies. Not even popular forms screen the horror: 'old shelters' (television, magazines, movies are cited) 'won't protect you anymore'. Words provide no succour: try 'scribbling' and then 'you'll discover you no longer trust the very walls you always took for granted' (2001: xxii). Text makes space violable, mutable, insecure. To want book as object is like wanting a securely demarcated world of words and things: 'I wanted a closed, inviolate and most of all immutable space' (2001: xix). By way of negatives and beyond the generic contours that allow some bearing to be taken, horrorspace starts to emerge: 'uncontained', slipping limits, categories and classifications, not fixed, bounded or unchanging.

The house is not a safe space, nor does it even comfort being with an expansive nothingness. ${ }^{8}$ A domestic space constitutes the primary locus of horror, recalling a tradition of ghostly and gothic tropes. Uncanny effects are readily evinced, theories in support. ${ }^{9}$ Family histories and personal traumas are extensively examined in citations of numerous critical debates about the cause of the spatial anomalies. Found footage, like the discovered manuscripts of Horace Walpole and Ann Radcliffe, and in echo of The Blair Witch Project's low-tech formal innovation, offers deceptive verification. Pages of 'facts' stage an effective interplay between science and mystery. 
Horrorspace in House of Leaves begins with the appearance of a hallway where no hallway should be. And an impossible empirical observation: when measured between its internal walls, the house is slightly larger on the inside than the size of the external walls, the former exceeding the latter 'by 1/4"' (2001: 30). Such a small difference opens to immensity. Experienced explorers try to plumb the impossible space, travelling for days along passageways, through rooms, halls, down huge staircases, only to find more space unfolding before them: an 'even larger entrance', 'an even greater void' (2001: 84). Windowless and dark, space weighs heavy; they lose bearings without finding centre or outside, their 'desire for exteriority', apparently 'amplified by the utter blankness found within', thwarted by internal dimensions 'spawning yet another endless series of empty rooms and passageways, all with walls potentially hiding and thus hinting at a possible exterior' (2001: 119). 'Facts' are detailed: no light, humidity, air movement, sound (apart from an occasional growling); no magnetism, objects, dust, the space manifests huge variations in size and depth and claims several human lives (2001: 370-71). Samples of minerals are taken and sent off for analysis. A detailed geological report, almost entirely erased by a spillage of ink, offers disarming results: the abyss exceeds a depth of 54,500 miles, impossible given Earth's radius (2001: 305); dating mineral deposits reveals the void is billions of years old - older than the solar system - with interstellar, possibly meteoric, components (2001: 378). Science baffled by its own measurement, the imagination thwarted in the face of unending darkness, representation collapses in labyrinthine complexity and reduplication -in a minimal fissure, the void of one wall.

The space between one wall is briefly occupied by Karen Navidson, in and outside the house at the same time, 'trapped between two thresholds' (2001: 347). It is experienced during attempts to record explorations on film: metaphorically encapsulating an entire life as the 
gap between two frames; written out, an 'aftermath' to meaning, a few words at a time, over several pages, 'A life time finished between the space of two frames. The dark line where the eye persists in seeing something that was never there To begin with' (2001: 196205). The non- or no-space of this single dark line, a minimal fissure, provides a striking contemporary innovation to traditions of horrorspace. The space between one wall is not that of unseen but ubiquitous inquisitorial tyranny; nor is it the gloomy oppression of disciplinary and carceral space or its opium dream counterpart. Nor do the deceptive shimmering of interiors and diseased imagining capture its superficially dense horrors, nor figural entanglements of wall coverings absorbing mental breakdown, not even the machinations in which morbid psyches and haunted houses find unity (see Radcliffe 1981: 305; De Quincey 1986: 103-07; Poe 1986: 120, 151; Gilman 1992: 254; Jackson 2005: 171). The void, too, is almost sublime, but without light promotes an oppressive sense of enclosure rather than wonder - a Gothic cathedral without chiaroscuro, huge subterranean cavern, prison or dungeon, it has 'Great Hall', enormous anteroom, 'spiral staircase'. Artificial illumination (there are no windows in this place) and camera lighting barely penetrate the darkness. Initial investigations by the homeowner and acclaimed photojournalist Will Navidson find a disturbing, almost substantial, 'oily darkness'. Enclosed by nothing, walls receding, without directional cues, even 'the floor begins to assume a new meaning. It can no longer be taken for granted'(2001: 67). The solidity of physical reality vanishes: walls move, space and position undergoing 'constant shifts', 'a layout in no way reminiscent of any modern floorplans let alone historical experiments in design' (2001: 120). Unprecedented strangeness and 'resistance to representation' makes even a 'schematic' impossible: a torn and fractured space - a 'schismatic' is all that is left as space turns hostile and psycho (2001: 109). ${ }^{10}$ 
Early investigations register a 'growl' amid the darkness (2001: 7, 67, 84). Subsequent exploration corroborates auditory anomalies and accentuates intimations of some beastly Thing at the edges of feeling and hearing: a 'heaviness' lurking out of reach, 'crouching, ready to spring, just a few feet away' (2001: 118). Monstrosity inhabits horrorspace. It spreads from void to house to head to text. It has claws: the room in which the first editor died has four marks on its floor, 'all of them no longer than a hand, jagged bits of wood clawed up by something neither one of us cared to imagine' (2001: xvii). Registered in the world outside the film record, claws and metonymic beast shadow text and reading: Truant senses something just beyond the words, 'some tremendous beast crouched off in the shadows, muscles a twitch from firing its great mass forward, ragged claws slowing extending, digging into the linoleum' (2001: 27). The horror in the novel and the horror of the novel replicate each other: 'inside a long dark hallway already caressed the other music of a single word', fear is assuaged in allusion to 'a thousand and one possible claws' (2001: 49). Like the disorientating housespace, the text he reads transforms his spatial location: 'the more I focused on the words the further I seemed from my room' (2001: 43). His head assumes its image, a 'bad-off labyrinthine brain' just as reading occasions similar effects to that of the explorers: a sense of something approaching, a roar; he feels 'walls crack' as 'the floor beneath' 'falls into a void' (2001: 51, 150). Involution and interpenetration of inside and out, reality and fiction, spatial and psychic disorientation: groundless and boundless, with no floor, no fixed walls or boundaries, dark, substantial absence provokes anxiety. Horrorspace inhabits those who inhabit it.

\section{Reading}


Reading and exploring horrorspace are equated. For all the interpretation and critical commentary it inspires, the short first version of the film documentary 'Five and a Half Minute Hallway' is considered 'meaningless' but 'not without effect' (2001: 60). Not that it matters: 'it makes no difference that the documentary at the heart of this book is a fiction', comments Truant, 'what's real or isn't real doesn't matter here. The consequences are the same' (2001: xx). Reality evaporates as fiction embraces both visual documentary and written collage, leaving the narrative sustained by the spatial, psychological and textual effects of horror. Domestic void, textual evacuation: no grounds or guarantees are offered, inside or out. ${ }^{11}$ Zampanò, who assembles the fragments in the first place, may be no more than another fiction, a 'nom-de-plume', his efforts expended on 'a film which doesn't even exist' (2001: xix). Reality returns to the writing that frames it, which perhaps fabricated it in the first place - film analysis of a non-existent documentary (like Paul Auster's The Book of Illusions, 2002) brings film to life though its scenes are shot nowhere other than in prose. The density of media criticism that makes it real, however, is further complicated: first, a prize-winning photojournalist is trying to capture 'the most difficult subject of all: the sight of darkness itself' and, second, the editor analysing the footage is 'blind as a bat' (2001: xxi). Inconsistency - visual medium and invisible subject - underlines impossibility to disclose the active emptiness of the novel as a labyrinth of self-reference and self-fabrication: evacuating reality as it constructs documentary realism, it openly celebrates its own vacuity and fictional artifice while reiterating a central empty topos as its own creation, its own selfdefining presence-absence effect. From Navidson's film to Zampanò's identity, reality is extracted by duplicitous self-reference. Further reverberations hollow out Truant: attempting to finish the project, find a grain of truth to underpin it and to maintain his own sense of self, he is increasingly consumed by doubts about the existence of any reality 
whatsoever, even his own. Fiction has cast a pervasive and inescapable net over everything. Acknowledging the dangerously interdependent relationship with the text he is editing, his confusion explodes, self 'derealized and depersonalized', suffering a 'disorientation so severe' as to believe that the text has created him as

nothing more than the matter of some other voice intruding through the folds of what even now lies there agape, possessing me with histories I should never recognize as my own; inventing me, defining me, directing me until finally every association I can claim as my own [...] is relegated to nothing, forcing me to face the most terrible suspicion of all, that all of this has just been made up and what's worse, not made up by me or even for that matter Zampanò. (2001: 326)

Evacuated of identity and reality, dissolved in a rippling web of fiction, the only touch of substance comes from an invisible and horrifying absence evoked by the inventive and entangled tissues of textual allusion and metaphoric material. ${ }^{12}$ The housevoid is made up of 'inky darkness' (2001: 155). Ink and menace shape Truant's horrifying experience in the tattoo parlour, his feeling of being attacked by that ragged clawed beast conjoined with a fevered fall, splattered by black and purple tattoo ink (2001: 70-71; see Hayles 2002: 790). The materiality of print that is highlighted - ink imprinting skin and page - also informs his image of his unspecified 'darkest angel' and 'horror of horrors' in whose wings he becomes enfolded: those wings are 'black as ink' (2001: 327). Feeling increasingly textual, his one material guarantee is also reflexive: ink and paper. The Navidson Record discloses a curious interdependence: 'I'm its source, the one who feeds it, nurses it back to health - but not 
life, I fear - bones of bond paper, transfusions of ink, genetic encryption in xerox' (2001: 326). His identity is but a mirror effect and material image of the text: he, too, in nurturing the fragments that feed on him, is no more than paper-skin, blood-ink, Xerox-code, a replication in a chain of replication.

Replication reduces things to the same image and simultaneously reiterates it, a collapse and expansion at once. Expanding references, but within one book: lists upon lists of names, of writers, articles, books (many actual, many fabricated) piled up in footnote upon footnote, an obsessive attempt to uncover the secret of the house by burying it in critical references also seems to curtail, embrace, pre-empt and exhaust interpretation before it can begin, in the manner of Alasdair Gray's Poor Things (1992). Initial footage ('Five and a Half Minute Hallway') is noted for its predisposition to interpretation by various schools of critical thought (2001: 4). Formally, too, the reflexivity expands and contracts to nothing, from the mention and dismissal of Glas to the printing of a black square. The former - with its two main cross-read columns (with additional boxes, segments, extended footnotes) articulating Hegelian thought and Genet's fiction - typographically instantiates the doubly thread labyrinth of writing in an impossibly philosophical-anti-philosophical form. But, of course, it has not been read, as a superfluous note makes clear: 'I merely wanted Glas (Paris: Editions Galilée, 1974). That is all. But the bastards reply it is unavailable. Swine. All of them' (2001: 545). Maybe the translation suffices, but probably not. The black square, another formal citation, offers more direct play with the limits of representation and meaning in print. It sits on a page crossed by columns, lines, citations, in a section concerned with critical discussions of documentary realism and photographic truth, within a square of print that runs not only up the page but 'in-verso': the words are reversed to suggest transparency, letters printed on the verso page read - through the paper and from behind 
as it were - on the previous recto page. In context, it is appropriate: the inversion of photographic negative, the absence of light, the black screen when the reel runs out, a (nonJrepresentation of blacked-out reality. Even if it means nothing, non-representation signifies. While it refers back to itself materially - to print, ink, paper - it refers also to a child's drawing later in the text: Chad, one of the Navidson children, is asked by his teacher to draw a picture of his house. He delivers 'nothing more than a black square filling ninety percent of the page', 'several layers of black crayon and pencil had been applied so that not even a speck of the paper beneath could show through' (2001: 313). Of course, this prompts serious pastoral concern, suggestive of family trauma, domestic abuse. An image under erasure, blacked out, conventional and familiar domestic representation violently voided, it is, given the properties and effects of the house, a telling version: present absence (aggressive black crayon technique) an effective and reflexive (non-)representation: everything comes back to the horrorspace of the househeadtext. Implosion extends to formal literary formal reference, notably the black page of Tristram Shandy's rendition of mourning (Sterne 1985: 61).

Collapsing inwards, House of Leaves also continues its expansive allusive trajectory, reiteration always returning, like a black hole, to its own gravitational collapse. Truant, already evacuated and reimagined as material-textual invention of unknown and possibly fictional origin, continues his search for a shred of reality to anchor his editing. He ends up in Flagstaff, Arizona, enters a bar where a band is playing. He catches a snippet of lyric, nonplussed by what he thinks he hears: ' 1 live at the end of a Five and a Half Minute Hallway' (2001: 512). Enquiries about the song, entitled 'Five and a Half Minute Hallway', reveal it was 'inspired' by a work the drummer had 'found on the Internet some time ago' (2001: 513). He is handed a tattered brick of printed paper, the book, title page and all: 
'House of Leaves by Zampanò with introduction and notes by Johnny Truant' (2001: 513). This Truant has not yet finished his edition. Yet here it is. Moreover, when on tour the band often meet audience members in other cities who ask about the song and profess knowledge of the book: they have 'spent many hours with complete strangers shooting the shit about Zampano's work', discussing footnotes and even coded names that Truant had 'transcribed without ever detecting' (2001: 514).

Text suddenly opens out and closes up. Reality is affirmed - the text exists - and scattered to the wind: its existence is both general and unspecified, its provenance obscure. Origins and authority are simultaneously verified and contradicted, subjected to two incompatible sources at once, scholarly bibliomania and digital replication. A shared delusion, a madness of writing, in which printed leaves return to the same text while radiating across another medium. ${ }^{13}$ In the process, however, ideas of originality cede to anonymous online dissemination, organic matter (leaves, paper) scattered and reassembled as electronic bits, downloaded and printed, closely read and discussed in numerous different sites. Is each audience member another Johnny Truant, replicating the gesture of discovering a manuscript beyond his own and doing it time and time again? Is it some kind of infinite mirroring, seeing himself, over and over again, mise en abyme, or a fractal iteration of algorithmic fragments repeated and reassembled like pixels in no-space, the same image forming and circulating in different places at once ${ }^{14}$ Does it matter? The text expands, replicates and consumes itself.

\section{Overwrite}


This is not the only place House of Leaves appears in House of Leaves. At the end of an incredible journey - days and days cycling through the house - Navidson, tired, increasingly disoriented, low on food, water and light, finds himself at the ultimate abyss: 'all that remains is the ashblack slab upon which he is standing, now apparently supported by nothing: darkness below, above, and of course darkness beyond' (2001: 464). At this point what can be done? Read, of course. He takes out a book called 'House of Leaves' (2001: 465):

First he reads a few lines by match light and then as the heat bites his fingertips he applies the flame to the page. Here then is one end: a final act of reading, a final act of consumption. And as the fire rapidly devours the paper, Navidson's eyes frantically sweep down over the text, keeping just ahead of the necessary immolation, until as he reaches the last few words, flames lick around his hands, ash peels off into the surrounding emptiness, and then as the fire retreats, dimming, its light suddenly spent, the book is gone leaving nothing behind but invisible traces already dismantled in the dark. (2001: 467)

A poetic final image of reading as consumption, text expending meaning, work and sense in self-destruction. A final contraction, an implosive ignition and dissipation: brief flames flickering and fading into emptiness and darkness. The book consumes itself in its own space of literary invention, in the emptiness of its own constructed void. Reading, consuming, burning: as if the destruction of the book and the evacuation of meaning constitutes the end 
of the text, a sacrificial material expenditure testifying to something palpably immaterial. ${ }^{15}$ Despite the repetitions of the signifier 'final', the text is not yet done.

Textual expansiveness and collapse - the scale of the housevoid and the thin, dark line of minimal difference - conjoin in a labyrinth of uncertain, or at least ambivalent, determination: a bibliotextual maze - palimpsestical layers of textual allusion, an interminable library of fragments folding back repeatedly on the empty space of its own textual formation - and multiple medial forms, signalling a consummation in hypertextual and virtual space without modern contours or human horizons. Rather than repeated selfreflection, mise en abyme, it suggests informatic iterations, recursive, fractal overwriting of all precedents. At the start, the trunk of manuscript fragments describe an 'endless snarls of words, sometimes twisting into meaning, sometimes into nothing at all, frequently breaking apart, always branching off into other pieces' (2001: xvii). Already the growling of textlabyrinth is heard as words entwine in their incomplete network. Manuscript material, moreover, speaks to the diversely fragmentary nature of composition: not unadulterated pages or tidy notebooks, but all sorts of leftover paper: 'old napkins', 'tattered edges of an envelope' or the 'back of a postage stamp' make up the manuscript, every scrap and space covered in ink, 'bits crisp and clean, others faded, burnt or folded and refolded so many times the creases have obliterated whole passages of god knows what...' (2001: xvii). These fragments, used for other purposes and discarded, are not signs of a writing culture. They are its waste, leaving blank spaces on which to scrawl. In part, the novel's incorporation of textual materiality uses waste matter, suggesting the obsolescence of both writing and materiality: the scraps are 'bits' in a new sense, binary units of information. Nor do the fragments compose a palimpsest (commenting successively in the margins of a textual core elided, effaced in layers of errant interpretation): the blank edges and folded shreds, used 
napkins or old envelopes, allow new scribblings, new informational patterns, with reference only to blank space. A form of excess inscription, of 'overwriting', corresponds less to an efflorescence of written style desperate to communicate the meaning its own colourings consume, and more to the 'overwrite' (or 'insert') button that deletes old text in the typing of new letters, electronic processing unhampered by history or prescription.

Readings of House of Leaves have engaged with its images of maternity, its parodies of scholarship and engagement with concerns of being (Cox 2006; Belletto 2009; Slocombe 2005) but have tended, with significant reservations, to highlight issues of hyperlinks, formatting, online release and immersion in multimedia networks: the 'dangers of hypertext' and its attempts, in the face of postmodern superficiality, to make a 'recovery of' and 'return to' reality and truth claims (Brick 2004; Toth 2013: 182; see also Hagler 2004; Pressman 2006; Spooner 2006: 41-47). Leading the way, Hayles connects the novel's inclusion of multiple types of mediation to attempts to 'save' the subject, lost to postmodern and post-human simulations, through a recuperation of literary forms and techniques. Through an immense effort of absorption that sees the reflexivity of the novel's form embrace (and exhaust) other media forms, it returns to the materiality of the printed book. Yet it is unclear whether the text is situated at the 'rebirth of the novel or the beginning of the novel's displacement by a hybrid discourse that as yet has no name' (2002: 781). It replays - an escalation or exhaustion even - of postmodernist concerns with reality and representation, its 'characteristic' crises and affirming 'that there is no reality independent of mediation' in order to display 'what print can be in a digital age' and 'recuperates the vitality of the novel as a genre by recovering, through the process of remediation, subjectivities coherent enough to become the foci of the sustained narration that remains the hallmark of the print novel' (2002: 781, original emphasis). Acknowledging 
its own media-materiality in its avowed attention to paper, ink, typography, while writing about other forms, from film, to television, Internet and code, it 'attempts to eat all other media' (2002: 781). But at a cost: the subject it saves can no longer consider its self an external or independent agent and origin since consciousness is 'evacuated as source' and recovered as 'mediated subjectivity' (2002: 785). Even the void is an effect of mediation: it 'creates an absence at the centre of the presence manufactured by the multiple layers of interpretation' (2002: 787-88). While nothing is present, absence assumes substance: 'there's nothing here' (Danielewski 2001: 4) only makes sense if considered as a substantive, 'a negation converted into a looming threat of something'. 'Materiality thus emerges from the interplay between physical attributes and semiotic components', subjects and realities effects of movements between layers of media-materialities (Hayles 2002: 788-89, original emphasis). Just as the 'nonexistent' film is 'created' as an object in and of the text through multiple remediations, voiding and retroactive reconstitution makes print seem real, less like remediation - in which a story transfers from one technology of telling to another - and more like affective fabrication. Mark Hansen suggests how - as a digital fiction - the novel produces its own sense of reality through affect: engaging with a whole 'media ecology' pertaining to an age of ubiquitous information, it discloses a void of referentiality, in which ontological difference is as inconsequential as replaying tired postmodern games of simulation, and eschews orthographic recording - in which a past reality is preserved while the singularity of experience it has evoked disappears. Thus, its reality comes as affect: realism engendered, not through representation, but by triggering the 'projection of a world' in the process of reading (Hansen 2004: 601). The void it makes shifts from orthographical dependence on reality and, through the 'textual deformation' of formal, typographical and literary inventiveness, foregrounds digital forms as the 'wholesale 
substitution of the productive imagination', the 'triumph of fiction over documentation' with affect as belated and immaterial guarantor of any sense of reality for the reader (2001: 610).

In both readings, mediation and voiding are crucial. Before any sense of subjectivity or literature can be recuperated, an evacuation of prior mediations (including writing) makes affect predominate over reality. But where is the horror? The novel is only 'camouflaged as a haunted house tale' (Hayles 2002: 779). Yet its deployment of 'low' literary techniques seems inseparable from its indulgence in higher modes of textual jouissance (supposing, after postmodernism, such distinctions are at all viable). Articulating different modes of reading, horror, if nothing more, enables both the registration of a palpable void and a powerful, anxious sense of ungraspable presence, an affective limit at which energies can expend themselves and, rebounding, return to something that feels like subjectivity and reality. ${ }^{16}$ As fictional and affective ground to groundless mediation, generic limits enable a negative sketch of boundless horror. Final shots, like early comments, recall genre: the sequence filmed after the family's removal to a New England town is taken at the end of October: 'Halloween. Jack O'lanterns. Vampires, witches, and politicians. A whole slew of eight year old ghouls haunting the streets of Dorset, plundering its homes for apples and MilkyWays, all while tossing up high-pitched screams into the sparkling blackness forever closing above them' (2001: 527). Happy, familiar scenes of darkness, dressed up appropriately and safely: horrorspace is contained or expunged; the failed 'shelters' of form and formula have, it seems, been repaired. The narrative commentary reads comforting generic reflexivity differently, insisting on a higher aesthetic tone. The scene 'gives a wink to the genre his work will always resist but invariably join' but does not finish 'with the caramel covered face of a Caspar the friendly ghostly'; more artistic, it insists on an image of lasting 
truth: 'he focuses on the empty road beyond, a pale curve vanishing into the woods where nothing moves and street lamp flickers on and off until at last it flickers out and darkness sweeps in like a hand' (2001: 527-28). Another image of darkness, another visual presentation of (non-)representation (a return to the haunting image of the house-void), more artistic perhaps, yet still a gothic chiaroscuro. Neither one nor other works alone, the interplay is crucial: reflexive at two levels, the relation between the scenes' more and less generic recognizability establishes the difference and the affect.

Reflexivity is not an aesthetic property reserved for literature: horror fictions since the eighteenth century repeatedly reflect on their textual status and form as discovered manuscripts (or film footage), reflect on their provenance, readership, and the witnesses, informants, letters, historical documents or empirical evidence that secure their veracity and elongate their mystery. Indeed, repetition-escalation of familiar generic forms and effects defines the excess of horror and circumlocutes the potent and fabricated fictional absence around which it turns, the screaming, fainting or shuddering bursts of intense and voiding affect that it evokes. Two registers - formulaic and reflexive - accompany horror. When Karen Navidson is captured on camcorder in a bedroom she is manifestly unaware of horror unfolding behind her and on-screen: only the wall is in focus, on which children's pictures hang; it suddenly 'vanishes into an inky blackness' (2001: 417). Her eyes on the recorder, Karen does not notice the 'horror looming up behind her', waiting for her, until she sees the screen and turns round. If this, for the viewer-reader, constitutes a moment of high, metaphysical horror (it encapsulates the behindness of Heideggerian anxiety), seeing what is behind and yet to come, already immersed in what the character cannot yet see, plays up a generic excitement and frustration akin to pantomime: 'it's behind you!' Formulaic and reflexive levels also shape the reading process: eighteenth-century romances 
often traced a division between overly curious or credulous readers immersed in the story and those retaining rational and moral judgement. In House of Leaves reading and readings multiply and entangle, always and at least on two levels. In horror, the novel maintains a 'page-turning' mode that is often frustrated by critical and reflexive digression (Hayles 2002: 796); it seduces attention with mystery as effectively as the characterization that garners literary potency. Truant is carried by the 'curiosity' (textual desire) driving him from word to word so that hours pass without him noticing (2001: xviii). No subject, no literature, it seems, without horror: it is their constitutive fissure, the darkness of their wall.

House of Leaves recuperates literature in a return to that pre-literary void, that stunning, groundless, productive absence composed of artifice and affects clawed out by Sade and the tales of terror. If its labyrinths, mad redoublings, echoes, fissures, growls and claw marks return, via horror, to literature in order to save its modern subject, then its engagement must be both naïve and parodic, riven by a curious birth that always duplicates images of death. Any return to horror does not get beyond its dynamics of excess and exhaustion, limit and repulsion, but is threatened with the same fate, wearing out in the very excess of subjective, cultural and generic limits. Without form, limits disappear, excess meaningless. Constructing potent absence from medial layers to engender effects of the real (intense affect notably) remains tied to the digital contemporaneity and postmodern crises that it attempts to encompass and exhaust, not so much wearing out the 'tired' games of simulation but activating them against themselves, a fourth order of hyper-real selfreference turning on and to a modern third order in which simulacra indicate absence (Baudrillard 1983: 11). Its return to literature and subjectivity is thoroughly marked by the conditions it proposes to escape: returning to the terrors of literary modernity frames any sense of nostalgia for disarming absence as a postmodern gesture - a nostalgia for the 
nostalgia of the absence of narratives (Lyotard 1979: 41). The moebial flip side (both same and other simultaneously) to the text's trajectory of literary recuperation - of reality or affect - is 'ontological indifference' and digital fiction. House of Leaves is already and inescapably bound to an emerging order of hypertext, digitality, immateriality, convergence... already consumed. Appealing to the fissure constituting modernity ploughs a digital wake toasting a shift from the void-structure characterizing modernity to that of posthumanity. Flows of informational pattern and randomness engender new immaterial voids, flatdepth pixellating to infinity. If absence is but an effect of the density of medial surfaces and layers, can its horrifying, anxiety-provoking weighty presence be sustained in flatscreens' no-space, animated by autonomous programs? If text devolves to digital infinity, replaying an already exhausted and exhaustive post-representational flight, is subjectivity little more - like Truant - than an erring iteration of other programs? 'Saving' no longer connotes redemption or recovery: to be 'saved' is simply to be stored in digital memory, electronically suspended (Curtis 2015). If modern horror caused subjectivity to shudder in the face of repulsive vitality, it is now consigned to a geo-archaeological burial ground called the 'anthropocene'; posthumanity flickers on. Space changes on-screen: indifferent convergence, immersive patterns and effaced materialities, pasts and futures enveloped in random access and real time. Surroundings, space, screens and selves merge in evental mediaspaces. Pervasive horrorspace loses hold and intensity as on-screen mimesis gives itself over to a quickly clickable, facile and minimally affective disposition: 'like'. What is left when the horror of absence cedes to the absence of horror?

\section{References}


Augé, M. (1995), Non-Places (trans. John Howe), London and New York: Verso.

Bachelard, G. (1969), The Poetics of Space (trans. Maria Jolas), Boston: Beacon Press.

Bataille, G. (1985), 'The labyrinth', in Allan Stoekl (ed.), Visions of Excess: Selected Writings, 1927-1939, Minneapolis: University of Minnesota Press, pp. 171-77.

(1988), 'Attraction and repulsion I and II', in Denis Hollier (ed.), The College of

Sociology 1937-1939 (trans. Betsy Wing), Minneapolis: The University of Minnesota Press, pp. 103-24.

(1995), “" Architecture”, "Slaugherhouse", "Space”,, in Robert Lebel and Isabelle Waldberg (eds), Encyclopedia Acephalica, London: Atlas Press, pp. 35-36, 72-74, 75-79.

Baudrillard, J. (1983), Simulations, New York: Semiotext(e).

Belletto, S. (2009), 'Rescuing interpretation with Mark Danielewski: The genre of scholarship in House of Leaves', Genre, 42: 3-4, pp. 99-117.

Botting, F. (1994), 'Dracula, romance and Radcliffean Gothic', Women's Writing, 1:2, pp. 181-201. (2012), 'More things: Horror, materialism and speculative weirdism', Horror Studies, 3:2, pp. 281-303. 
Brick, M. (2004), 'Blueprint(s): Rubric for a deconstructed age in House of Leaves', Philament, 2 (January),

Sydney.edu.au/arts/publications/philament/issue2 Critique Brick.htm. Accessed 10/12/ 2014.

Caillois, R. (2001), Man and the Sacred (trans. Meyer Barash), Urbana and Chicago: University of Illinois Press.

Cox, K. (2006), 'What has made me? Locating mother in the textual labyrinth of Mark Z. Danielewski's House of Leaves', Critical Survey, 18:2, pp. 4-15.

Curtis, S. (2015), 'You have been saved: Digital memory and salvation', in C. Spooner and F. Botting (eds), Monstrous Media/Spectral Subjects, Manchester: Manchester University Press, pp. 157-70.

Danielewski, Mark Z. (2001), House of Leaves, London and New York: Doubleday.

De Quincey, T. (1986), Confessions of an English Opium Eater (ed. Aletheia Hayter), London: Penguin.

Derrida, J. (1997), “'Architecture where Desire may Live” and "Points de Folie - Maintenant L'Architecture"', in Neil Leach (ed.), Rethinking Architecture, New York and London: Routledge, pp. 319-24, 324-36. 
Eco, U. (1984), Name of the Rose (trans. William Weaver), London: Pan.

(1985), 'Reflections on "Name of the Rose"' (trans. William Weaver), Encounter, 25 April, pp. 7-18.

Ehrmann, J. (1971), 'The death of literature', New Literary History, 3:1, pp. 31-47.

Eisenman, P. (1992), 'Unfolding events', in Jonathan Crary and Sandford Kwinter (eds), Incorporations, New York: Zone, pp. 423-26.

Foucault, M. (1970), The Order of Things, London: Tavistock.

(1977), 'Language to infinity', in Donald F. Bouchard and Sherry Simon (eds), Language, Counter-Memory, Practice (trans. Donald F. Bouchard and Sherry Simon), Ithaca: New York: Cornell University Press, pp. 53-67.

(1980), 'Of other spaces', Diacritics, 16:1, pp. 22-27.

(1998), 'On the ways of writing history', in James D. Faubion (ed.), Aesthetics, Method, and Epistemology (trans. Robert Hurley), New York: New Press, pp. 279-95.

Gibson, W. (1986), Neuromancer, London: Grafton. 
Gilman, Charlotte P. (1992), 'The yellow wall-paper', in Chris Baldick (ed.), The Oxford Book of Gothic Tales, Oxford: OUP, pp. 249-63.

Hagler, S. (2004), 'Mediating print and hypertext in Mark Z. Danielewski's House of Leaves', Mode, 1.1. english.arts.cornell.edu/publications/mode/documents/hagler.html. Accessed $10 / 12 / 14$

Hansen, Mark B. N. (2004), 'The digital topography of Mark Z. Danielewski's “House of Leaves"', Contemporary Literature, 45:4, pp. 597-636.

Hayles, N. K. (1999), How We Became Posthuman, Chicago and London: University of Chicago Press.

(2002), 'Saving the subject: Remediation in House of Leaves', America Literature, 74:4, pp. 779-806.

Heidegger, M. (1962), Being and Time (trans. John Macquarrie and Edward Robinson), Oxford: Blackwell.

Hollier, D. (1989), Against Architecture (trans. Betsy Wing), London and Cambridge, MA: MIT Press. 
Kant, I. (1929), Critique of Pure Reason (trans. Norman Kemp Smith), London and Basingstoke: Macmillan.

Kristeva, J. (1982), Powers of Horror: an Essay in Abjection (trans. Leon S. Roudiez), New York: Columbia University Press.

Jackson, S. (2005), The Haunting of Hill House, London: Penguin.

Lacan, J. (1992), The Ethics of Psychoanalysis (trans. Dennis Porter), London: Routledge. (2014), Anxiety (trans. A. R. Price), Cambridge: Polity.

Levinas, E. (1986), 'Dialogue with Emmanuel Levinas', in Richard A. Cohen (ed.), Face to Face with Levinas, Albany, NY: SUNY Press, pp. 19-33.

(1989), 'There is: Existence without existents', in Sean Hand (ed.), The Levinas Reader, Oxford: Blackwell, pp. 29-36.

Lyotard, Jean-Francois (1979), The Postmodern Condition: A Report on Knowledge (trans. Geoff Bennington and Brian Massumi), Manchester: Manchester University Press. 
Otto, Rudolf (1950), The Idea of the Holy (trans. John W. Harvey), Oxford: OUP.

Poe, E. A. (1986), The Fall of the House of Usher and Other Writings (ed. David Galloway), London: Penguin.

Pressman, J. (2006), 'House of Leaves: Reading the networked novel', Studies in American Fiction, 34:1, pp. 107-28.

Radcliffe, A. (1981), The Italian, or the Confessional of the Black Penitents (1797) (ed. Frederick Garber), Oxford: Oxford University Press.

Schwenger, P. (1993), 'Agrippa, or, The Apocalyptic Book', South Atlantic Quarterly, 92:4, pp. 617-26.

Slocombe, W. (2005), "'This Is Not For You": Nihilism and the House the Jacques Built', Modern Fiction Studies, 51:1, pp. 88-109.

Spooner, C. (2006), Contemporary Gothic, London: Reaktion.

Sterne, L. (1985), The Life and Opinions of Tristram Shandy (ed. Graham Petrie), London: Penguin.

Toth, J. (2013), 'Healing postmodern America: Plasticity and renewal in Danielewski's House 
of Leaves', Critique, 54:2, pp. 181-97.

Tschumi, B. (1996), Architecture and Disjunction, Cambridge, MA and London: MIT Press.

Vidler, A. (1992), The Architectural Uncanny, London and Cambridge, MA: MIT Press. (2000), Warped Space, London and Cambridge, MA: MIT Press.

Voller, J. (1993), 'Neuromanticism: Cyberspace and the sublime', Extrapolation, 34:1, pp. $18-29$.

Worringer, W. (1964), Form in Gothic (trans. Herbert Read), London: Alec Trivanti. (1997), Abstraction and Empathy (trans. Michael Bullock), Chicago: Ivan R. Dee.

\section{Contributor details}

Fred Botting is a Professor of English Literature at Kingston University. He has published widely on literary theory, gothic writing and horror. His books include the second edition of Gothic, Gothic Romanced (Routledge, 2014 and 2008), Limits of Horror and Sex, Machines and Navels (Manchester University Press, 2008 and 1999).

Contact: 
Department of English, Holmwood House, School of Humanities, Kingston University, Penrhyn Rd, Kingston on Thames, Surrey, KTI 2EE, UK.

E-mail: f.botting@kingston.ac.uk

Notes

${ }^{1}$ Where, as 'noumenon', the-thing-in-itself serves a rational delimitation of an 'empty' and distracting domain beyond categorical knowledge and sense (Kant 1929: 272-23), its nonphilosophical counterpart marks a place of subjective decomposition and protection, a barrier against a threatening and intimate beyond and site of projections that screen and screen off horror's full effects (Lacan 1992: 208, 298, 232).

${ }^{2}$ Levinas (1989: 32). Horror rustles, murmurs and menaces subjectivity, an encounter with being that strips 'private existence' into an 'undifferentiated background' with 'no exits', a space 'full of the nothingness of everything' (Levinas 1989: 33). Prior to institutions of moral law and judgement this 'dis-interested' space announces an implacable absolute ethical alterity (Levinas 1986: 29-30).

${ }^{3}$ Anomalous, anonymous, accursed, amoral, ambiguous, asubjective, asemantic, abject: abjection is positioned between subjects and objects, its spillages and flows of energies, fluids and feelings engendering repulsions, disgust, abhorrence, all refusing containment and structure and dissolving boundaries (Kristeva 1982: 3-5). But it also strangely underpins culture, subjectivity and body, a 'primer' and 'safeguard' that succeeds material and symbolic dissolution in reconstitutions of forms that are sublime and even sacred (Kristeva 1982: 17). 
${ }^{4}$ Just as metaphor provides the spatial contours and coordinates to determine a relation to the world, so architecture offered the metaphors of solidity and stability, a 'baseline' for reality: 'bricks and mortar, house and home, structure and foundation were the metaphors that anchored our reality - what constitutes reality today is not so clear' (Eisenman 1992: 423). Jacques Derrida notes the defining spatialization allowing us to 'appear to ourselves': instituted by architecture that 'constructs' and 'instructs' at the same time, a legacy that is 'naturalized' and 'inhabits us', it inaugurates 'the intimacy of our economy, the law of our hearth (oikos)', family, politics, religion, 'all the places of birth and death, temple, school, stadium, agora, square, sepulchre' traversed by a forgotten historicity and rendered as 'common sense itself' (1997: 326).

${ }^{5}$ Horror, in concert with dread and terror, touches on the wholly other, the sacred. Primitive fears - 'demonic dread' - furnish objects and social bonds with alluring and potent fascination pertaining to the holy, the 'numen praesens', an utterly other entity felt to be 'objective and outside the self' presiding over rituals, customs, beliefs (Otto 1950: 16-29). The sacred - in festivals, sacrifice, worship - is often violent and tumultuous, engendering excesses at once erotic, animalistic and divine; wasteful, destructive but intensely meaningful pursuits of value and heterogeneity. Groups and social bonds are constituted by a 'sacred nucleus' that is 'dark, repulsive', turbulently creating 'life out of the category of death': it shows humanity united 'by disgust and common terror', conjoined in 'insurmountable horror' (Bataille 1988: 114). Polarized, the sacred embraces the fascination of the flame and the horror of putrefaction (Caillois 2001: 42). The polarity defines religion, temples, places of both sacrifice and butchery. Modernity introduces separation: over time, museums, galleries, parks fulfil a quasi-sacred function (what good citizens do for 
ennoblement in their Sunday leisure time), while abattoirs assume an accursed and increasingly abject role: in contrast to the ideals of bourgeois art, the 'good folk' only perceive 'their own unseemliness', their own cleanliness, meanness, boredom marking selfexile in a 'flabby world in which nothing fearful remains' (Bataille 1995: 74). Active, violent yet meaningful festivals - 'holy days' - cede to abjection or emptiness: hollow bourgeois morality and production mirrored precisely in the absence of work - a 'vacation' (Caillois 2001: 127).

6 'Gothic space is unbridled activity' (Worringer 1964: 159): inimical to abstraction and stemming from a primitive 'immense spiritual dread', it stems from early human insecurity in the face of threatening and indistinct environments (an 'unending flux of being') (Worringer 1997: 15-17). Northern European architecture repudiates both space itself and beautiful classical forms: its cathedrals 'animate the inorganic', 'vitalize geometry' and display how 'matter lives solely in its own mechanical laws'; restless attempts to order space deliver a 'blissful vertigo', a 'spectrally heightened' but 'distorted actuality' in this mechanically spiritualized uncannimation of grotesque ghosts and things (Worringer 1964: $77,112,115)$. Space convulses in formlessness, unruliness and unrest. It is a 'lout', 'as discontinuous as it is devious', insubordinately breaking 'all obligatory continuity' in a 'pure violence which escapes time' (Bataille 1995: 77-79); like the crowds and mobs that cathedrals, palaces and monuments attempt, through awe, to silence and suppress, it exudes the 'bestial monstrosity' escaping architecture's straitjacket (Bataille 1995: 36). ${ }^{7}$ So, too, architecture: the project to reconstruct Parc de la Villette (site of a nineteenthcentury Paris slaughterhouse) by Bernard Tschumi moves away from postmodernism, eschewing 'excesses of style', whether Doric supermarkets, Bauhaus bars or Gothic condos, 
that have divested architecture of meaning (1996: 176). After postmodernity, we inhabit 'fractured space': Tschumi proposes a post-human practice dispersing subjects and replacing bodily proportionality by 'grids and modular systems' - models consonant with Deleuze's 'control society' (1996: 222). 'Autonomous abstract systems' made up of 'points, lines and surfaces' contaminate relations and spaces (1996: 186). Superimposable pointgrids and lines in 'constant production, continuous change' reject the 'symbolic repertory of architecture as a refuge for humanist thought', no longer a matter of masterful design, or filling in gaps: it dismantles (deconstructs) previous historical layers to enable 'multiple combinations and substitutions' (Tschumi 1996: 201, 191). Unsurprisingly - by way of plans, papers, digital schematics and theoretical reference - it opens a different textspace: 'excentric, dis-integrated, dis-located, disjunction, deconstructed, dismantled, disassociated, discontinuous, deregulated' (1996: 225). Physical reality is reshaped and relativized: 'energy, as well as matter, is a discontinuous structure of points: punctum, quantum' (1996: 219); the disparate grid structure of varying red cubes allows varied traversal of the Parc's multiple connections (1996: 197). Like the contemporary city, it is redefined in terms of codes and cells, as 'fragmentation, parcellization, atomization' (1996: 218). Architectural permanence - 'buildings as solid, made of steel, concrete, glass' - is challenged by 'immaterial presentation' - 'from television to electronic surveillance' (Tschumi 1996: 216). Media, indeed, transform space. No longer a matter of structure or interpretation, architecture concerns mediation: people do not go to stadia or concerts to watch an event, but to 'become part of the environment', light, sound, screens, action and space forming 'an event-structure' in which building is 'consumed by media', space no longer fixed or framed but folded like a Deleuzian 'temporal modulation that implies a continual variation of 
matter' (Eisenman 1992: 425). A new world of information, grids and network provides the context for Michel Foucault's discussion of heterotopias (1980: 22) - but with much less, if anything, of the sacred to be found. Denis Hollier's criticism of Tschumi draws out this absence: La Villette is not a place of sacrificial or carnivalistic expenditure or a place where 'emptiness is experienced', or, even, a site 'to appropriate and discipline proletarian expenditure': it 'makes room for educational parks, spaces where workers on holiday see demonstrated the meaning of their work' (Hollier 1989: xiv). As such it is another 'nonplace' of supermodernity, a specified site of interest marked off from places invested by identity, locality and culture by a world of omni-screened events, media-networks, communications relays and transit points (motorways, junctions, services, terminals, hotels, shanty-towns; incessant mobility, of passengers, commodities, information; digital displays to an excess of signs invading space; while a general solitude of non-social exchanges is manifested by the 'unmediated commerce of wordless supermarkets') (Augé 1995: 99, 78). ${ }^{8}$ Gaston Bachelard's discussion of 'felicitous space' elaborates how houses are 'seized upon by the imagination' to become spaces of intimacy and memory: enclosed, protected, warm, they 'constitute a body of images that give mankind proofs or illusions of stability' and, as refuges, embody human virtues (1969: 3-7, 17, 46). Calibrated to a spectrum of sadness and joy, a 'poetic space' expands objective dimensions providing things with 'more space than it has objectivity' (1969: 202). Even nothingness has a comforting aspect: citing Goyen's House of Breath (1950), where security and homeliness found in the walls and words of home also evoke a sense of nothingness, caressing and protecting being: yet 'against this background of nothingness human values grow' (Bachelard 1969: 58). 
${ }^{9}$ Heidegerrian and Freudian versions are cited on page 24 and page 28 . For the former the uncanny manifests a falling away of a world dominated by others and prefabricated ideas defining a particular being and, without pre-given coordinates of subject and object, anxiety registers the encounter with something neither visibly here nor there - the world's 'essentially spatial Being-in': 'what threatens is nowhere' but not nothing - 'grounded in the most primordial "something" - in the world" (Heidegger 1962: 230-32, original emphasis). In psychoanalysis the decomposition of familiar coordinates also involves anxiety, registering neither absence - it makes itself felt when something appears in a no longer natural place nor lack (felt when a 'central void' is filled); it is a 'different sort of object': intruding too much, disturbing spacings securing structured symbolic realities of self, object and, of course, home, its discloses something, beyond structural repression or the imaginary, that 'has never passed through the twists and turns, the networks, the scene of recognition' (Lacan 2014: 41, 61, 76).

${ }^{10}$ La Villette's design was conceived under the auspices of 'folies' - madness and architectural follies: 'just as all collectivities require lunatics, deviants and criminals to mark their own negativity, so architecture needs extremes and interdictions to inscribe the reality of its constant oscillation between the properties of the built realm and the absoluteness of its concepts' so that grids and lines suggest an asylum's or a prison's bars (Tschumi 1996: 175-79). A maddening design of fragments and partial exchanges dissociating meaning across a 'pinpoint weave of an ensemble which, also, includes lines and surfaces'. Weave becomes labyrinthine abyss (Derrida 1997: 325-26). Like Bataille's labyrinth of words, it is unruly and intoxicating, introducing 'schizogenesis into lexical space, multiplying meanings by inverting and splitting them', making words 'drunk' (Hollier 1989: 60). 
${ }^{11}$ Home is not secure. Haunted, it is also pressed by changing presents, its space reconfigured according to political-architectural imperatives. Tschumi's departure from humanism leaves its bodies behind, returning to a 'body in pieces', an 'exhaustion of corporeality' that has 'no comforting referent', only 'vertigo, sudden vertical and sideways movements, and even potential dissection': its trajectory towards a body of cells, of exteriorized cell-structure becoming the 'object of spatial modelling' (Vidler 1992: 111). Homes are not immune, changing according to different pressures: the 1920 s and 1930 s 'Taylorized' homes as a 'kitchen-house-factory' run by domestic engineers (Vidler 1992: 161); now information flattens it according to pressures of 'technological competency', reducing space 'to the flat surface of the monitor': 'a "machine for living in" has been transformed into a potentially dangerous psychopathological space populated by halfnatural, half-prosthetic individuals, where walls reflect the sights of the viewers, where the house surveys its occupants with silent menace' (Vidler 1992: 161).

${ }^{12}$ Webs, words, walls: Bataille's labyrinth is not just a matter of sacrificial tauromachy, but entwines existence and language. Each life is entwined in words - never autonomous, only 'being in relation': 'one need only follow for a short time, the traces of the repeated circuits of words to discover, in a disconcerting vision, the labyrinthine structure of the human being' (1985: 72-74). It is a 'space wherein oppositions disintegrate and grow complicated, where diacritical couples are unbalanced and perverted' (Hollier 1989: 58).

${ }^{13}$ La Villette's 'folies' operate according to a 'principle of heterogeneity', 'of multiple, dissociated, and inherently confrontational elements', disrupting 'smooth coherence of reassuring stability in composition, promoting instability and programmatic madness' (Tschumi 1996: 201). A textual madness, too: 'palimpsest and supersedimented textuality, 
bottomless stratigraphy that is mobile, light and abyssal, foliateal, foliiform Foliated folly. Foliage and folie [mad] not to seek reassurance in any solidity: not in ground or tree, horizontality or verticality, nature or culture, form or foundation or finality' (Derrida 1997: 332). Madness of walls and words, papers, sheets, scattered leaves weaving labyrinths; of texture: grids, lines and networks, a 'network-stratagem' 'spacing a multiplicity of matrices or generative cells whose transformations will never let themselves be calmed, stabilized, installed, identified in continuum' (Derrida 1997: 332) Leaves, cells, codes, chromosomes, the madness envelops a generative matrix, network space, a no-space somehow maintaining a relation to alterity. In contrast, Foucault's madness delivers a more destabilizing yet formative fissure between disciplinary norms and deviance, 'a space before the constitution of the subject, before the institutionalization of subjectivity', one that is 'anterior to the division between madness and reason': like the unruliness of Bataillean space, it is an 'asubjective, asemantic space of an unedifying architecture' (Hollier 1989: x). ${ }^{14}$ From the 'artificial desktop infinity' that expands and contracts on computer screens to the mental 'nonspace' of cyberspace in which data unfolds in visual grids directly in the brain, space cedes to information (Voller 1993: 20; Gibson 1986: 67). But information may have 'no inherent spatiality', leaving a question of 'life without space', of the 'absolute "void" without space or time - "no-space"' (Vidler 2000: 234-35). Flatness, screens: space appears as program 'windows'; its subject 'caught in a matrix, a web, a space of no-time and no place' (Vidler 2000: 243-45).

${ }^{15}$ Jacques Ehrmann's 'death of literature' describes the subversion of reading-writing as consisting in 'setting fire to the powder, of activating the flames - of burning, igniting meaning' (1971: 45). A digital art collaboration offers a technical update: a disc forming part 
of the collaborative artwork - Agrippa - undertaken by William Gibson and Dennis Ashbaugh contained a memoir that destroyed itself on reading: 'when the disk has run its course, everything in the text [...] is encrypted into a mechanized code [...] before it contorts and vanishes' (Schwenger 1993: 625). At the end of The Name of the Rose, in the aftermath to a climactic conflagration that sees a great and labyrinthine library burn to the ground, the narrator is left to pick among the remains of burnt books and assemble his own small library of textual remains (Eco 1984: 500). Webs of modern writing, fall, in ashes, from the heights of enlightened aspiration and the protection of carefully catalogued mazes of shelves: the totality of knowledge they hold is a pinnacle and preserve of human attainment and aspiration, both sacred and scary, and, in the dangerously entwined paths they promise, take the form of a labyrinth: one entrance and exit determine their structure, a 'mannerist' mirror to the clear path of enlightened human knowledge. It is distinct from Eco's first examples of a labyrinth: the classical maze in which civilization penetrates with cunning and force to kill the beast at its centre. His third labyrinth moves out of modernist - and humanist - frames: with 'no centre, no periphery, no exit', it takes the form of Deleuze and Guattari's rhizomatic assemblage (Eco 1985: 15). All points entangle in a network neither hierarchical nor arboreal, approximating densely superficial webs of electronic interconnection in which anchors of materiality and reference have little bearing on the circulation of information.

${ }^{16}$ Michel Foucault's writings on literature locate its emergence at a very precise point in the history of modern horror - in terror, labyrinths, voids, doubles, claws and affect. His thinking is informed by a nightmare in which he finds himself speechless in the face of a text he can neither read nor make sense of. It allows him, however, to discuss a writing that exceeds 
humanity, not serving representation or communication, but turning 'towards a darkness we know nothing about': a writing torn from reason, reference and sense, dividing itself; a language outside all work that 'furrows all written language' to leave 'an empty claw mark on every text' (1998: 290). The nightmare recapitulates the fissure underpinning modernity's reorganization of words and things and the literary illustration with which that study is prefaced: Borges' Chinese encyclopaedia discloses a space within and in excess of classification, its 'bestiary of the imagination' confounding-destroying all order or possible relations by dispatching of the 'very site in which their propinquity would be possible' (Foucault 1970: xvi). It exposes heterotopia in a most radical form (1970: xix). By way of 'ataxonomia', the text demonstrates 'words and categories that lack all life and place, but are rooted in a ceremonial space overburdened with complex figures, secret passages and unexpected communications' (1970: xviii). Labyrinth of words and walls, web of figures and fissures, its void of self-reference and excess expenditure shrouded by the brilliance of darkness and terror: a 'language to infinity' performing 'radical exhaustion' in the stimulation of pure affect, a hollowing, within speech, an iteration warding of imminent death in a repetitive murmur reduplicating its non-place (1977: 55-59). Foucault identifies in specific and rigorous terms - the period and the avatars of this emergence: the late eighteenth century with the texts of Sade and the tales of terror - writings 'drawn out of themselves by the overwhelming, the unspeakable, by thrills, stupefaction, ecstasy, dumbness, pure violence [...]' (1977: 60). Untied from reference, enunciation or presence, writing spins out a language of affect and irony split between an superabundant reflexivity and deficiency of grounding, between naivety and parody, between immersed, shocked reading and a display of writerly tricks: a 'forked language that turns against itself from 
within', an excess without any 'ontological weight' pushing 'back to infinity this limit it bears within itself' while it 'appropriates and consumes all other languages in its lightning flash' (1977: 66). Suitably labyrinthine, the argument returns to Borges and his dark, rigorous and playfully perverse house of words, 'The Library of Babel'. 